\title{
MicroRNAs in B cell development and malignancy
}

\author{
Thilini R Fernando ${ }^{1 \dagger}$, Norma I Rodriguez-Malave ${ }^{1,2+}$ and Dinesh S Rao ${ }^{1,3,4,5^{*}}$
}

\begin{abstract}
MicroRNAs are small RNA molecules that regulate gene expression and play critical roles in B cell development and malignancy. miRNA expression is important globally, as B cell specific knockouts of Dicer show profound defects in B cell development; and is also critical at the level of specific miRNAs. In this review, we discuss miRNAs that are involved in normal $B$ cell development in the bone marrow and during B cell activation and terminal differentiation in the periphery. Next, we turn to miRNAs that are dysregulated during diseases of B cells, including malignant diseases and autoimmunity. Further study of miRNAs and their targets will lead to a better understanding of B cell development, and should also lead to the development of novel therapeutic strategies against $B$ cell diseases.
\end{abstract}

\section{Introduction}

In a relatively short time period, gene expression regulation by microRNAs (miRNAs) has changed the way that we view developmental and pathological processes. From initial discoveries in C. elegans, the identification of the novel small RNA biogenesis pathway and the identification of RNA interference, the field has moved rapidly [1-6]. The involvement of miRNAs in hematopoiesis has now been documented by numerous groups and they seem to regulate almost every aspect of hematopoietic development. In this review we focus on B cell development, where the importance of gene expression regulation has been appreciated for many years. miRNAs have emerged as critical regulators of gene expression and regulate many aspects of B cell development, and are dysregulated in B cell malignancies. Here, we review many of the studies that have been performed to delineate the roles of miRNAs in development and malignant transformation of B cells.

\section{MicroRNA biogenesis}

miRNAs are non-protein coding RNAs of about 19-23 nucleotides. They are post-transcriptional gene regulators that bind to partially complementary sequences in the 3' UTR on target messenger RNA transcripts, thereby causing downregulation of the target [7]. They

\footnotetext{
* Correspondence: drao@mednet.ucla.edu

+ Contributed equally

'Department of Pathology and Laboratory Medicine, UCLA, 10833 Le Conte Avenue, Los Angeles, CA 90095, USA

Full list of author information is available at the end of the article
}

were first discovered in 1993 in C. elegans by Victor Ambros, during a study of lin-14. They identified a small RNA product encoded by lin-4 gene that is responsible for the downregulation of LIN-14 protein $[2,3,8]$. This central dogma of miRNA action has proven to stand the test of time, as miRNAs in most organisms are thought to behave similarly.

miRNAs can be grouped in to at least three categories depending on their genomic location: exonic miRNAs in non-coding genes, intronic miRNAs in non-coding genes and intronic miRNAs in protein-coding genes [9]. miRNAs are expressed as long primary RNA (primiRNA) as part of RNA polymerase II-driven transcript [10]. Therefore, it is possible that some miRNAs are coregulated with their host gene as a part of transcriptional regulation during $\mathrm{B}$ cell development. The primiRNA is recognized by RNA binding protein DGCR8 and is processed by RNase III-type protein Drosha in the nucleus yielding a pre-mRNA [11,12]. Pre-miRNA is then exported to the cytoplasm by Exportin-5 where it is further processed by a second RNase III-type enzyme, Dicer, to produce a mature miRNA duplex [13]. The 19-25 nucleotide-long double stranded miRNA duplex is then unwound and incorporated into RNA-induced silencing complex (RISC), with strand selection based on thermodynamic properties. In the RISC, the miRNA binds to the target sequence in the 3' UTR via 6-8 nucleotide seed region and downregulates the expression of the target either by direct degradation or destabilization and eventually degradation of the target [14-16]. Since the repression is achieved by

\section{Biomed Central}


complementary base pairing via a relatively short seed sequence, miRNAs are predicted to have multiple targets. A genome wide statistical analysis has shown that one miRNA can have hundreds of targets, indicating their critical role in post translation regulation [17]. It should be noted that recently, a Dicer-independent miRNA biogenesis pathway has also been reported. This pathway utilizes the catalytic activity of Argonaute2 (Ago2) [18-21]. miR-451 is the best characterized miRNA that is produced independently of Dicer and is involved in erythropoiesis. The unusual short stem structure of pre miR-451 promotes the binding and processing by Ago2 [19].

miRNAs have already found to influence immune cell differentiation. Recently, it was found that Dicer and miRNA play vital roles in both early and late B cell differentiation [22,23]. Deletions of individual miRNA genes are associated with several immune defects. In many instances, dysregulated expression of miRNAs has been seen in malignancies in the immune system, which we will discuss in detail later in the review.

\section{B cell development}

B cells are responsible for adaptive humoral immunity. B cell development is characterized by complex sequence of molecular events that is regulated by $\mathrm{B}$ lineage transcription factors. It is evident that miRNAs play a major role in modulating the expression of these transcription factors and thereby the normal development of B cells. Conversely, dysregulation of miRNA expression is thought to be a key factor to the pathogenesis of $B$ cell malignancies, including progenitor B cell-malignancies such as B-lymphoblastic leukemia (also referred to as B-Acute lymphoblastic leukemia or B-ALL) and mature B cell malignancies including several types of non-Hodgkin lymphoma. B cell development begins in the fetal liver and continues in the bone marrow of adult throughout the life (reviewed in $[24,25])$. The process of B cell formation starts in the bone marrow and ends in the peripheral secondary lymphoid organs such as the spleen (Figure 1). Here, we provide a primer on $\mathrm{B}$ cell development to orient the discussion on the role of miRNAs in B cells.

\section{Bone marrow B cell development}

In the bone marrow, cellular stages of development include the common lymphoid progenitor, pro-B cell, pre- $B$ cell and immature- $B$ cell stages. These stages of $B$ cells are defined by the expression and the re-arrangement of functional B cell receptor (BCR)/immunoglobulin (Ig) genes. Complex and elegant mechanisms have evolved to generate a diverse repertoire of BCRs against the vast variety of antigen that we encounter in our lifetime. This diversity is achieved by $\mathrm{V}(\mathrm{D}) \mathrm{J}$ recombination of the immunoglobulin locus, which is a process of somatic recombination that brings together various gene segments within the heavy and light chain loci. The heavy chain is assembled from Variable (V), Diversity

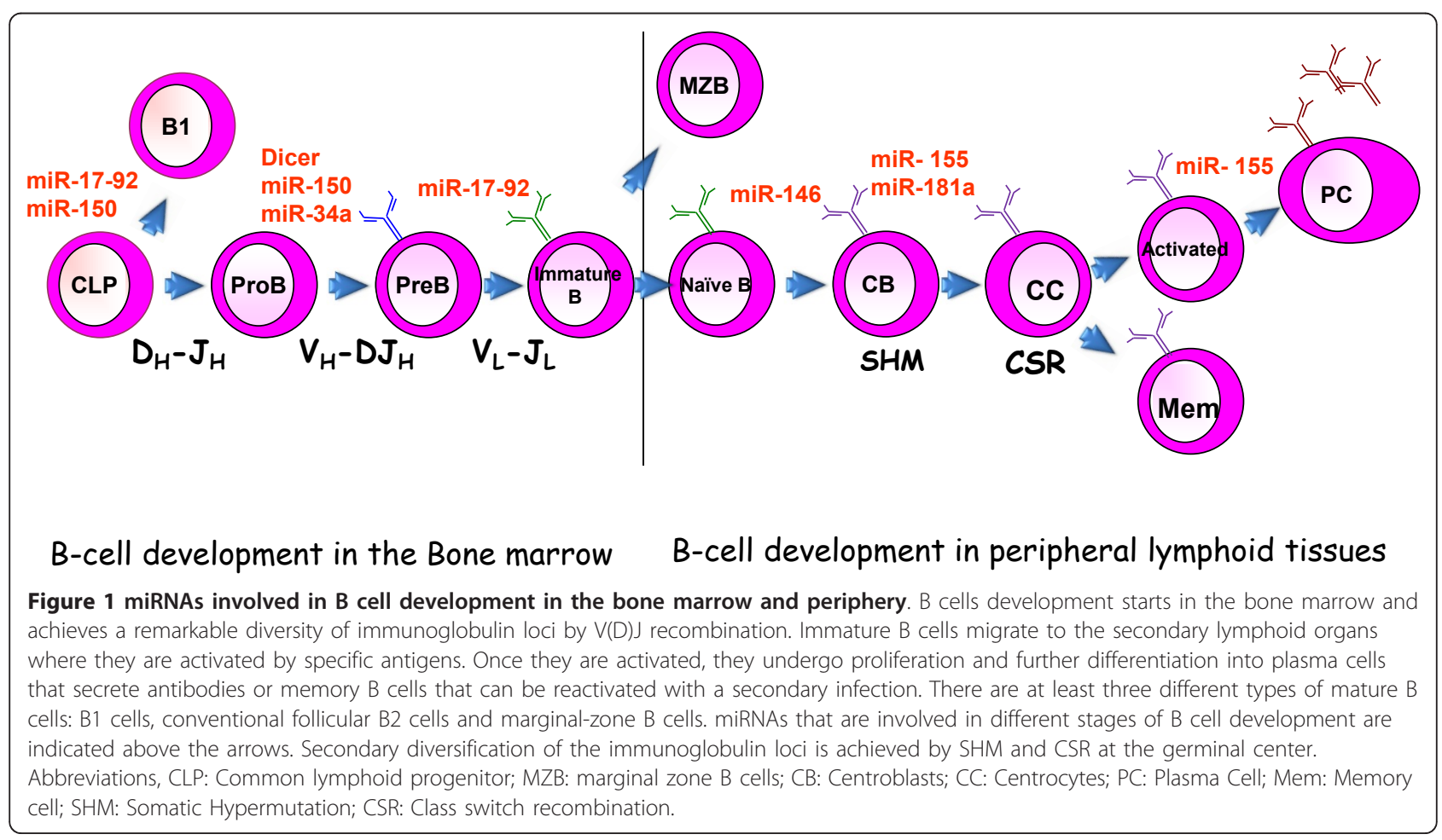


(D) and Joining (J) gene exons that somatically recombine with the Constant $(\mathrm{C})$ region exons to generate unique immunoglobulins of differing antigenic specificity. On the other hand, the light chain variable region is composed of only a $\mathrm{V}$ and $\mathrm{J}$ segments. The numbers of these gene segments are highly variable in different species and the different segments seem to have evolved from gene duplications from ancestral $\mathrm{V}$-gene exons. Each V-, D-, and J- gene segment is flanked by DNA sequence called recombination signaling sequence, which is recognized by RAG1 and RAG2 enzymes, which mediate recombination. Random selection of these segments during $\mathrm{V}(\mathrm{D}) \mathrm{J}$ recombination and junctional diversity introduced by addition or subtractions of nucleotides at the junctions of these segments enable the production of vast variety of Ig (reviewed in [26-32]).

The stages of B cell development have been defined by the steps in $\mathrm{V}(\mathrm{D}) \mathrm{J}$ recombination. The Pro-B cell stage is characterized by rearrangement of Ig heavy chain, which occurs first. D-J joining occurs first, following which the DJ segment is joined to a V segment. D-J rearrangement starts in the common lymphoid progenitor and occurs mainly in early pro-B cells. V-DJ rearrangement occurs in late pro- $B$ cells. The assembled heavy chain is then expressed on the surface of the pre-B cells along with a surrogate light chain. The pro-B cell to pre- $\mathrm{B}$ cell transition is accompanied by cell proliferation. Rearrangement of the light chain by $\mathrm{V}$ to $\mathrm{J}$ joining occurs during the pre-B cell stage. Successful assembly of light chain leads to the expression of complete IgM molecule at the surface and if the rearrangement is successful, signal transduction from IgM binding allows for differentiation into an immature B cell. Immature B cells that are not self-reactive leave the bone marrow as transitional B cells. Self-reactive immature B cells will either undergo apoptosis (clonal deletion), generate a new $B$ cell receptor by receptor editing, or become unresponsive to antigen (reviewed in [26-29,31,33]).

Several transcription factors including PU.1, STAT5, E2A (E12 and E47), EBF, Pax-5, IKZFI and FOXP1 together with cytokines (IL-7, SCF) and chemokines (CXCL12), which are provided by the stromal cells, regulate the commitment and maintenance of $\mathrm{B}$ cells (reviewed in [34,35]). Absence of IL-7 signaling leads to developmental arrest at the pre-pro-B cell stage, showing the essential role of IL-7 signaling in B cell development in mice [36]. Downstream of IL-7, deletion of both STAT5 and STAT3 lead to developmental arrest at the pro-B stage $[37,38]$. Transcriptional regulation of B cell development is complex and involves the interplay of several transcription factors, including E2A, EBF, PAX5, FOXP1 and IKZF1. E2A-null mutant mice were unable to generate mature B cells [39], while Pax-5 is required for commitment to the $B$ cell lineage [40]. Deletion of EBF blocked the pro-B to pre-B transition [41]. It has also been shown that $\mathrm{Ebf}^{-1-}$ hematopoietic cells do not express Pax-5 indicating that EBF acts upstream of Pax-5. This finding was further supported by the finding of an EBF-binding site in the Pax-5 promoter region [42]. Foxp1 is also an essential transcription factor for $\mathrm{B}$ cell development that is induced by E2A and in turn induces expression of the Rag enzymes. Deletion or knockdown of Foxp1 resulted in a reduction of $B$ cell specific gene expression and interrupted the transition from pro-B cell to pre-B cell $[35,43]$. Other transcriptional regulators of $B$ cell development include Ikzf1, which seems to play an important role in early lymphoid commitment.

These repeated cycles of DNA damage and repair may explain the reason for Pro- $B$ and pre- $B$ stages being more susceptible to oncogenic transformation. Also of interest, almost every transcriptional regulator of $\mathrm{B}$ cell development is disrupted in B-lineage malignancy. E2A has found in chromosomal translocations associated with B-ALL, and Pax-5 deletions are common in B-ALL [44-48]. Also in genome wide analysis, Pax-5 and EBF have been shown to be associated with B ALL [46]. Foxp1 translocation and overexpression is noted in mature B cell neoplasms, while IKZF1 is disrupted in pre-B-ALL [49-60]. Hence, the study of B cell development also informs the understanding of $\mathrm{B}$ cell malignancy pathogenesis.

\section{$B$ cell development in the periphery}

Mature $B$ cells in the periphery are generally divided into B1 and B2 cells. B2 cells are conventional B cells that are derived from the bone marrow, undergo $\mathrm{V}(\mathrm{D}) \mathrm{J}$ recombination, and are part of the adaptive immune response (reviewed in [26]). A second set of recently described B cells, called B1 cells, are characterized by a limited immunoglobulin repertoire, and are part of the innate immune system (reviewed in [61]). These are best described in the mouse lymphoid system, where they express distinct sets of markers and are located mainly in the peritoneum and in the spleen. The lineage origin and relationship with conventional B2 cells is not entirely clear. The rest of our discussion will focus on B2 cells.

The majority of the cells in the spleen and in the circulation are thought to be B2 cells, and we focus the rest of the discussion in this section of such cells. B cells that have not encountered their specific antigen are called naïve B cells (CD 27-, IgD+). When a B cell binds to an antigen, it enters the germinal center of peripheral lymphoid tissues and eventually differentiates into plasma cells and memory cells. Plasma cells are a terminally differentiated, highly specialized B cell that 
secretes massive quantities of Ig, and whose differentiation is mediated by activation of plasma cell transcription factors such as Blimp1 and Xbp1 [62]. Memory B cells are long-lived and can be re-activated during a secondary infection. The entry of the activated B cells into primary lymphoid follicles results in the formation of germinal centers (GCs). Follicles with germinal centers have three distinct zones, namely dark, light and mantle zone. Rapidly dividing B cells which are called centroblasts form the dark zone of the GC. CBs eventually differentiate into non cycling centrocytes which make up the light zone of the GC. In the GC, secondary diversification of the immunoglobulin repertoire is achieved through somatic hypermutation and class switch recombination [63]. During this remarkable process, CBs can refine the specificity of their antigen receptor by somatic hypermutation of $\operatorname{IgV}$ gene, via the introduction of point mutations. If this process results in enhancement of the binding affinity for antigen, the B cell is selected for, and it survives to differentiate further. Also during the germinal center reaction, class switching from IgM to any other immunoglobulin can occur. Here, the variable portion of the heavy chain ( $\mathrm{VH}$ exon) is brought adjacent to with different immunoglobulin constant regions ( $\mathrm{CH}$ exons). This process allows making antibodies with different effector function. Remarkably, both of these processes-somatic hypermutation and class-switch recombination-are under the control of the same enzyme, adenosine-induced deaminase (AID) [64]. CC expressing Igs with enhanced affinity may eventually be released as memory B cells (CD 27+) from the GC. These memory cells are long lived and have potential to become antibody secreting cells during secondary infection (reviewed in [29,32,65-67]).

\section{MicroRNAs in bone marrow $B$ cell development}

As can be seen from the preceding discussion, bone marrow B cell development is carefully orchestrated, as only one gene locus is rearranged at a given time in a fixed sequence. Ig rearrangement is mediated by the sequential action of a gene regulatory network composed of transcription factors and growth factor receptors. miRNAs are known to act as post-transcriptional regulators of gene expression and it therefore stands to reason that they play a critical role in this network. The importance of miRNAs was first established by a seminal study that delineated a role for miRNAs in hematopoietic lineage choice selection. In this study, the authors determined that miR-181 (now known as miR181a) was expressed most highly in B cells and that its overexpression in hematopoietic stem and progenitor cells led to increased output of B cells $[68,69]$. Further studies have shown additional miRNAs of importance in B cell development; in this section, we will focus on the role of miR-150, miR-34a and the miR-17-92 cluster in antigen independent $\mathrm{B}$ cell development at the bone marrow.

A general role for miRNAs in B cell development has also been established (Figure 1). The conditional knockout of Dicer in early B cells led to a developmental arrest at the pro- $\mathrm{B}$ cell to pre- $\mathrm{B}$ cell transition, and also caused an effect on antibody diversification [70]. Geneexpression profiling from Dicer-deficient cells indicated that Bim, a known miR-17-92 cluster target, was upregulated in the mice. Functionally, B cell development was partially rescued by concurrent Bim ablation in Dicer-deficient mice. The implication of these studies was that miR-17-92, via repression of Bim, was the key player that was missing in Dicer-deficient B cell development. The miR-17-92 cluster is located on chromosome 13 and encodes six different miRNAs. The cluster is highly expressed in progenitor B cells and expression diminishes as cells mature. Ectopic expression of the cluster in mice resulted in expansion and activation of all lymphocyte populations in the periphery [71]. Compound heterozygous mutations of two target genes of miR-17-92, Bim and Pten, resulted in an accumulation of activated lymphocytes, indicating that partial repression of two targets may explain the majority of the miR17-92-induced phenotype [71]. Taken together these data indicate that the miR-17-92 cluster plays a critical role in proliferation control in B cells, in B cell development and Ig rearrangement.

A second B cell-relevant miRNA, miR-150, is highly expressed in progenitor $B$ cells and levels decrease at the pro- $\mathrm{B}$ cell to pre- $\mathrm{B}$ cell transition. miR-150 targets the $\mathrm{c}-\mathrm{Myb}$ transcription factor in B cell development [72]. Confirming targeting, B cells that are deficient in miR-150 showed higher levels of c-Myb, while overexpression of miR-150 in transgenic mice caused reduced levels of c-Myb. Over-expression of miR-150 in mouse HSC led to a defect at the pro-B cell to pre-B cell transition [72]. Mice with targeted deletion of miR150 had more B-1 cells in the spleen and peritoneal cavity and fewer B-2 cells, although they appeared phenotypically normal [73]. Knock-out mice for miR-150 at baseline contained higher serum concentrations of Ig classes, especially IgA, likely due to an expansion of B-1 cells [72]. Similarly, mice that were haploinsufficient for c-Myb had fewer mature B cells in the spleen and fewer B-1 cells, consistent with what was seen with the miR150 transgenic mice [74] These data indicate a critical role for miR-150 during B cell development.

Along with miR-150, miR-34a is highly expressed in progenitor cells and downregulated and the pro-B cell to pre-B cell transition. Ig rearrangement has multiple check points dependent on TP53 [75]. TP53 targets miR-34a which in turn targets genes involved in cell 
cycle regulation, cell proliferation and apoptosis [76,77]. Among its targets are the anti-apoptotic protein, BCL2, and the transcription factor Foxp1 [43,78]. Mice with constitutive expression of miR-34a showed a block at the pro- $\mathrm{B}$ cell to pre- $\mathrm{B}$ cell transition with a reduction in mature B cells [43]. This arrest resulted from the inhibition of Foxp 1 which is required for early B cell development. These findings elucidate a crucial role for miR-34a regulation at early B cell development.

\section{MicroRNAs in spleen and periphery B cell development}

As in bone marrow B cell development, miRNAs as a whole, as well as specific miRNAs, have now been appreciated to play important roles in peripheral or antigen-dependent B cell development (Figure 1). At the global level, Dicer ablation in mature B cells (as opposed to early precursor B cells) using CD21-Cre resulted in an increase in marginal zone $\mathrm{B}$ cells and a decrease in follicular B cells [23]. Mice deficient for Dicer in mature B cells had an increased titer of autoimmune immunoglobulins with frank autoimmune disease in a proportion of the female mice. The mechanistic basis of these findings remains to be determined, but this study suggested that a miRNA may be responsible of regulating Bruton's tyrosine kinase. However, there are certainly some miRNAs that play major roles in B cell development; here we will focus on the role of miR-155, miR146a and miR-181a in B cell development in the spleen and periphery.

In normal lymphopoiesis, miR-155 is expressed in moderate level in HSCs, at high levels in the germinal center and at much lower levels in mature B cells [79-81]. Expression of miR-155 is rapidly induced in B cells after engagement of the antigen receptor and exposure to inflammatory mediators $[82,83]$. Mice lacking miR-155 showed normal steady state immune cell populations; however, mice had a defective humoral response when immunized [84]. This response involved impaired germinal center formation and led to low antibody class switching to IgG in a B cell-intrinsic manner. The targets responsible for this appear to be multiple but likely include PU.1, SHIP1, and possibly AID [85-87]). The inhibition of the latter target is interesting, because the phenotype that is observed in the miR-155 deficient mice is one of decreased class-switching, whereas derepression of AID might be expected to cause increased class switching. The targeting of AID by miR-155 was extensively studied by mutating the binding site for miR-155 in the AID 3'UTR and these studies determined that disruption of the interaction did indeed lead to increased class-switching, and hence the overall effect of miR-155 likely includes additional targets $[86,87]$. Overall, these data are consistent with miR-155 playing an important role in regulating antigen-dependent $\mathrm{B}$ cell development. More recently, a second miRNA has been identified to regulate CSR- miR-181b overexpression in $\mathrm{B}$ cells was found to reduce the CSR rates, possibly by also downregulating AID [88].

The miR-146 family has distinct expression patterns amongst various hematopoietic lineages and is involved in maintaining lineage identity in lymphocytes. Vertebrates have two genomic copies of the miRNA, miR$146 \mathrm{a}$ and miR-146b, although the latter is likely a pseudogene [89]. miR-146a is induced by Toll-like receptor 4 and latent membrane protein 1 activation, and is NF$\kappa \mathrm{B}$ dependent $[83,90]$. miR-146a targets IRAK1 and TRAF6, two adapter proteins involved in Toll like receptor and interleukin 1 receptor signaling [91]. The role of miR-146a in B cells remains to be definitively determined, but overall B cell numbers are lower in miR146a-deficient mice as the mice have a myeloproliferative disorder. Curiously however, many mice show dramatic follicular hyperplasia and active germinal centers with increased B cell function [92].

Some other miRNAs, including miR-125a, miR-125b, miR-99b and let-7e transcripts are preferentially expressed by the actively dividing centroblasts in germinal centers. In functional assays, miRNA-125b overexpression inhibited the differentiation of primary $\mathrm{B}$ cells [93]. Hence, it can be seen that several miRNAs show important roles during antigen-dependent $\mathrm{B}$ cell development.

\section{MicroRNAs in B cell lymphoma and leukemia}

The expression of miRNAs in a particular cell type (miRNome) can vary between normal and diseased tissues. The relationship between miRNAs and cancer was first appreciated when loss of miR-15a/16-1 was discovered in chronic lymphocytic leukemia (CLL) [94]. Also, the discovery that miRNAs were located in cancer-associated genomic regions (CAGRs) furthered studies of the miRNome in a vast number of cancers, from solid tumors to hematological malignancies $[95,96]$. The function of miRNAs depends greatly on the cellular context for they can act as tumor suppressor genes or oncogenes depending on the genes that are expressed in a given cell. In this section we will focus on miRNAs that have been implicated in B cell lymphoma and leukemia (Figure 2). We will focus our discussion on those miRNAs that have some functional role in B cell development or lymphoma; it is beyond the scope of this review to list the plethora of profiling studies that exist in the literature.

Dysregulation of miR-155 and the miR-15a/16 and miR-17-92 clusters has been implicated in B-ALL [97]. miR-155 overexpression has been observed in certain subtypes of ALL and its over-expression in mice gives rise to $\mathrm{B}$ cell lymphoproliferative disease by targeting 


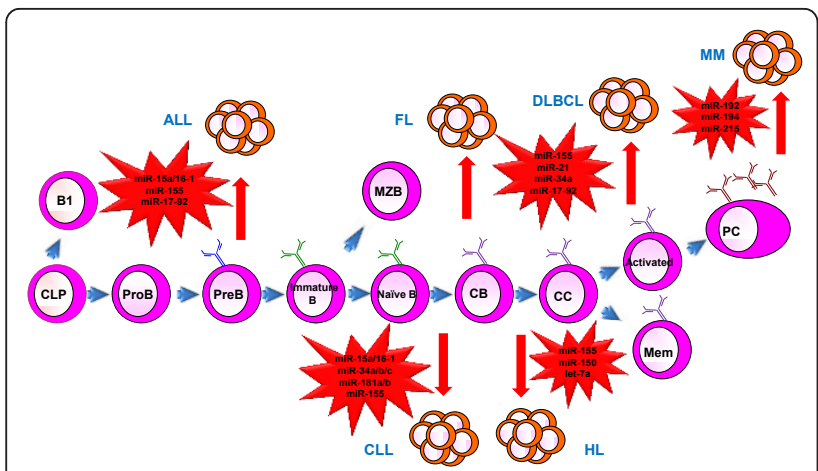

Figure 2 miRNA dysregulation leads to B cell malignancies. Dysregulation of key miRNAs at different stages in B cell development can cause malignant transformation and expansion. ALL: B-lymphoblastic lymphoma; CLL: Chronic lymphocytic leukemia; HL: Hodgkin lymphoma; NHL: Non-Hodgkin lymphoma; DLBCL: Diffuse large B cell lymphoma (a type of $\mathrm{NHL}$ ); FL: Follicular lymphoma (a type of NHL); MM: Multiple Myeloma.

the SHIP1 inositol phosphatase [98-100]. miR-16 targets anti-apoptotic genes BCL-2, MCL1 and CDK46, thereby acting as a putative tumor suppressor [101]. The miR17-92 cluster is upregulated in ALL due to copy number amplification and direct upregulation, and transgenic overexpression of this cluster leads to a lymphoproliferative disease in mice, as we have previously discussed (see preceding section on miRNAs and bone marrow B cell development $[71,97])$. Interestingly, overexpression of a single miRNA, miR-21, can lead to a high-grade B-ALL in mice and similar to protein-coding oncogenes, demonstrates the phenomenon of "oncogene addiction" [102].

In CLL miR-15a/16-1 dysregulation is observed along with dysregulation of miR-34a, miR-34b, miR-34c, miR181b, miR-181a and miR-155. In fact miR-34a expression has recently been validated as a prognostic marker in CLL in a fairly large clinical study [103,104]. It is interesting to note that one of the most frequent abnormalities in CLL is 13q14 deletion, and the search for candidate tumor suppressor genes in the deleted region had not been successful in the pre-miRNA era [105]. The minimal deleted region (MDR) within 13q14 contains a long non-coding RNA (lncRNA) named DLEU2 [106,107]. Carlo Croce and his colleagues found that the miR-15a/16- cluster was located within intron 4 of DLEU2 [95]. This identification of the first tumor suppressor miRNA was followed by extensive study and delineation of multiple targets [103]. However, the formal assessment of tumor suppressor function was completed much more recently. In an exacting study, DallaFavera and colleagues created conditional knockout mice with deletions of the minimal deleted region (MDR), deleting both DLEU2 and the miRNA, or of the
miRNA cluster only [108]. Remarkably, the mice with deletion of the miRNA only showed a pre-leukemic expansion of $B$ cells, while the mice with deletion of the MDR developed a CLL-like disease. In this study, the authors showed that there were likely multiple miRNA targets responsible for the phenotypes observed, including some that had been previously identified.

Dysregulation of miRNAs has also been described in Hodgkin's Lymphoma (HL) and Non-Hodgkin's Lymphoma (NHL). In NHL miR-155, miR-21, miR-34a and the miR-17-92 clusters have been implicated. miR-155 carries prognostic implications as high expression of the miRNA is typical of ABC-DLBCL which has a 5 year survival rate [109]. In vivo studies demonstrate an oncogenic role for miR-21 in B-lymphomagenesis [102]. Mice expressing miR-21 showed a pre-B malignant lymphoid-like phenotype and inactivating miR-21 caused regression of the malignancy. The miR-17-92 cluster is upregulated in approximately $65 \%$ of lymphomas [110]. Furthermore, let-7a, miR-150 and miR-155 are found dysregulated in HL. Let-7a is upregulated causing low expression of PRDM1/Blimp, presumably interrupting plasma cell differentiation [111]. Downregulation of miR-150 and upregulation of miR-155 is common in HL. In normal lymphopoiesis there are high levels of miR-155 in the germinal center, where HL has its origin, suggesting that miR-155 upregulation in HL is due to an abnormal block of lymphocyte differentiation at the germinal center stage [24].

Lastly, p53-mediated miRNA regulation has been found to be important in multiple myeloma (MM), a neoplasm of mature plasma cells. In an effort to understand the miRNA effectors of p53 in this context, Pichiorri and colleagues defined a set of p53-regulated miRNAs, which include miR-192, miR-194, and miR215 that are downregulated in a subset of newly diagnosed MM. These miRNAs target and downregulate MDM2, a negative regulator of p53. Hence, the expression of these miRNAs reinforces the activity of p53, and the authors found that enforced expression of these miRNAs had a negative effect on the growth of MM cells. Therapeutic possibilities are suggested by the effects of miRNA reconstitution in tempering MM cell growth [112].

The preceding discussion should establish the contribution of miRNAs in lymphoid tumorigenesis. Although some molecular effectors of the miRNnome are known, much remains to be discovered. miRNAs are likely to be of use as diagnostic biomarkers for cancer and as prognostic indicators. Additional work to uncover the roles of miRNAs as therapeutic agents remains to be completed, where a major limitation remains delivery of small RNAs into lymphoid cells. 


\section{MicroRNAs in autoimmunity}

Strong responses to self-antigens are thought to be the basis of autoimmune diseases. Many autoimmune diseases are heavily dependent on $\mathrm{T}$ cells, but $\mathrm{B}$ cells are almost certainly involved, for example, in the secretion of autoantibodies. Indeed mice with a conditional deletion of Dicer in mature B cells develop abnormal B cell subsets, have high autoantibody titers, and female mice develop autoimmune disease with end-organ damage. Several specific miRNAs have been found to be dysregulated in variety of autoimmune disease, and many have a role in T-cell function [113].

It has been found that miR-146a null mice develop a severe autoimmune disorder characterized by enlarged spleen and lymph nodes. These null mice produced about 60 fold higher amounts of autoantibodies against double standard DNA than wild type mice. Autoimmune phenotype in miR-146a null mice is consistent with the finding of elevated amount of activated $\mathrm{T}$ cells in the periphery, but may also be dependent on increased activation of B cells [89]. miR-146a also plays a role in the pathogenesis of Systemic lupus erythematosus (SLE). It represses the function of IFN (type one interferon), a factor that is important in SLE, by repressing the target genes such as TRAF6/IRAK1, STAT1 and TLR7 or TLR9 [114-117].

It has been found out that the generation and function of regulatory T-cells ( $\mathrm{T}$ reg) in autoimmunity is dependent on Dicer dependent miRNA biosynthesis pathway. Mice that have conditional deletion of Dicer in $\mathrm{T}$ reg cells showed early onset of autoimmunity which is similar to the observed phenotype in Foxp3 mutant mice that completely lack $T$ reg cells $[118,119]$. Later study showed that Foxp3 regulate the expression of miR-155 in $\mathrm{T}$ reg cells and deficiency of miR-155 results in decreased number, proliferation and fitness of $\mathrm{T}$ reg cells compared to wild type [120]. In a similar set of experiments, miR-146a-deficient hematopoietic cells failed to rescue Foxp3-deficient T-cell-mediated autoimmunity [121].

Although the role of miRNAs in B cell-mediated autoimmunity is less firmly established, it is likely that further discoveries in B cells are forthcoming. Finally, it has been shown in a pilot study that miRNA can be potentially used as biomarkers for diagnosis and prognosis of autoimmune diseases such as rheumatic diseases [122].

\section{Conclusions}

The advances in understanding the biological and pathological roles of miRNAs in B cells have been tremendous in the last few years. Despite this progress, there are many questions that remain. The first is how extensive are the networks that are controlled by
miRNAs in B cells? Although some studies, including our own, have shown that a single or few targets may be critical at a given developmental stage, it remains to be delineated whether this is generally true or if there are multiple targets that a miRNA regulates. A second major question, which remains largely unexplored in mammalian systems, is how miRNA degradation is regulated. This will help define how gene expression programs may be regulated at one stage but not another by a given miRNA. Lastly, the utilization of miRNAbased therapeutics in B cell malignancies and inflammatory conditions is an area of active research. There are several avenues of promising work that suggests that we will be able to leverage miRNA-based pathways in treating these diseases, but current challenges include delivery into specific cell-types [123]. Research into viral vector-based delivery and into chemically modified small RNA sequences are particularly promising, and are likely to be the next frontiers.

\section{Acknowledgements}

In this review we focused on those miRNAs that have some functional role in B cell development or lymphoma, thus we acknowledge that we may not have included many papers describing profiling studies on miRNAs. We would like to thank Jorge Contreras for his help and support in the completion of this article. TF is a recipient of Developmental Hematology Training Grant T32HL086345-05 from the National Institute of Health (NIH). NIRM is a recipient of the Eugene V. Cota-Robles Fellowship from UCLA and of the Graduate Research Fellowship Program from the National Science Foundation (NSF). DSR is a Kimmel Scholar of the Sidney Kimmel

Foundation for Cancer Research and received a career development award from the NIH (5 K08-CA133251).

\section{Author details}

'Department of Pathology and Laboratory Medicine, UCLA, 10833 Le Conte Avenue, Los Angeles, CA 90095, USA. ${ }^{2}$ Cellular and Molecular Pathology Ph. D. Program, Department of Pathology and Laboratory Medicine, UCLA, 10833 Le Conte Avenue, Los Angeles, CA 90095, USA. ${ }^{3}$ Jonsson Comprehensive Cancer Center, UCLA, 650 Charles E. Young Drive South, Factor 8-684, Los Angeles, CA 90095, USA. "BBroad Stem Cell Research Center, UCLA, 650 Charles E. Young Drive South, Factor 12-272, Los Angeles, CA 90095, USA. ${ }^{5}$ Division of Biology, California Institute of Technology, 1200 E. California Blvd, Pasadena, CA 91106, USA.

\section{Authors' contributions}

TF and NIRM participated in its design and coordination and drafted the manuscript. DR conceived of the review, and participated in its design and coordination and drafted the manuscript. All authors read and approved the final manuscript.

\section{Competing interests}

The authors declare that they have no competing interests.

Received: 16 February 2012 Accepted: 8 March 2012

Published: 8 March 2012

\section{References}

1. Fire A, Xu S, Montgomery MK, Kostas SA, Driver SE, Mello CC: Potent and specific genetic interference by double-stranded RNA in Caenorhabditis elegans. Nature 1998, 391:806-811.

2. Lee RC, Feinbaum RL, Ambros V: The C. elegans heterochronic gene lin-4 encodes small RNAs with antisense complementarity to lin-14. Cell 1993, 75:843-854. 
3. Ruvkun G, Giusto J: The Caenorhabditis elegans heterochronic gene lin14 encodes a nuclear protein that forms a temporal developmental switch. Nature 1989, 338:313-319.

4. Bernstein E, Caudy AA, Hammond SM, Hannon GJ: Role for a bidentate ribonuclease in the initiation step of RNA interference. Nature 2001, 409:363-366

5. Hammond SM, Boettcher S, Caudy AA, Kobayashi R, Hannon GJ: Argonaute2, a link between genetic and biochemical analyses of RNAi. Science (New York, NY 2001, 293:1146-1150.

6. Ketting RF, Fischer SE, Bernstein E, Sijen T, Hannon GJ, Plasterk RH: Dicer functions in RNA interference and in synthesis of small RNA involved in developmental timing in C. elegans. Genes Dev 2001, 15:2654-2659.

7. Ambros V, Lee RC, Lavanway A, Williams PT, Jewell D: MicroRNAs and other tiny endogenous RNAs in C. elegans. Curr Biol 2003, 13:807-818.

8. Wightman B, Ha I, Ruvkun G: Posttranscriptional regulation of the heterochronic gene lin-14 by lin- 4 mediates temporal pattern formation in C. elegans. Cell 1993, 75:855-862.

9. Kim VN, Han J, Siomi MC: Biogenesis of small RNAs in animals. Nat Rev Mol Cell Biol 2009, 10:126-139.

10. Lee Y, Kim M, Han J, Yeom KH, Lee S, Baek SH, Kim VN: MicroRNA genes are transcribed by RNA polymerase II. EMBO I 2004, 23:4051-4060.

11. Lee Y, Ahn C, Han J, Choi H, Kim J, Yim J, Lee J, Provost P, Radmark O, Kim S, Kim VN: The nuclear RNase III Drosha initiates microRNA processing. Nature 2003, 425:415-419.

12. Gregory RI, Yan KP, Amuthan G, Chendrimada T, Doratotaj B, Cooch N, Shiekhattar R: The Microprocessor complex mediates the genesis of microRNAs. Nature 2004, 432:235.

13. Lund E, Guttinger S, Calado A, Dahlberg JE, Kutay U: Nuclear export of microRNA precursors. Science (New York, NY 2004, 303:95-98.

14. Bartel DP: MicroRNAs: target recognition and regulatory functions. Cell 2009, 136:215-233.

15. Grimson A, Farh KK, Johnston WK, Garrett-Engele P, Lim LP, Bartel DP: MicroRNA Targeting Specificity in Mammals: Determinants beyond Seed Pairing. Mol Cell 2007, 27:91-105.

16. Lewis BP, Burge $C B$, Bartel DP: Conserved seed pairing, often flanked by adenosines, indicates that thousands of human genes are microRNA targets. Cell 2005, 120:15-20.

17. Brennecke J, Stark A, Russell RB, Cohen SM: Principles of microRNA-target recognition. PLoS biology 2005, 3:e85

18. Czech B, Hannon GJ: Small RNA sorting: matchmaking for Argonautes. Nat Rev Genet 2011, 12:19-31

19. Cifuentes D, Xue H, Taylor DW, Patnode H, Mishima Y, Cheloufi S, Ma E, Mane S, Hannon GJ, Lawson ND, et al: A novel miRNA processing pathway independent of Dicer requires Argonaute2 catalytic activity. Science (New York, NY 2010, 328:1694-1698.

20. Carmell MA, Xuan Z, Zhang MQ, Hannon GJ: The Argonaute family: tentacles that reach into RNAi, developmental control, stem cell maintenance, and tumorigenesis. Genes Dev 2002, 16:2733-2742.

21. Sasaki T, Shiohama A, Minoshima S, Shimizu N: Identification of eight members of the Argonaute family in the human genome small star, filled. Genomics 2003, 82:323-330.

22. Xu S, Guo K, Zeng Q, Huo J, Lam KP: The RNase III enzyme Dicer is essential for germinal center B-cell formation. Blood 2012, 119:767-776

23. Belver $L$, de Yebenes VG, Ramiro AR: MicroRNAs prevent the generation of autoreactive antibodies. Immunity 2010, 33:713-722.

24. Fabbri M, Croce CM: Role of microRNAs in lymphoid biology and disease. Current Opinion in Hematology 2011, 18:266-272.

25. Shaffer AL, Lin Kl, Kuo TC, Yu X, Hurt EM, Rosenwald A, Giltnane JM, Yang L, Zhao H, Calame K, Staudt LM: Blimp-1 orchestrates plasma cell differentiation by extinguishing the mature $B$ cell gene expression program. Immunity 2002, 17:51-62.

26. Hardy RR, Hayakawa K: B cell development pathways. Annu Rev Immunol 2001, 19:595-621.

27. Perez-Vera P, Reyes-Leon A, Fuentes-Panana EM: Signaling proteins and transcription factors in normal and malignant early $\mathrm{B}$ cell development. Bone marrow research 2011, 2011:502751.

28. Baltimore D, Boldin MP, O'Connell RM, Rao DS, Taganov KD: MicroRNAs: new regulators of immune cell development and function. Nature immunology 2008, 9:839-845.

29. Nagasawa T: Microenvironmental niches in the bone marrow required for B-cell development. Nature reviews Immunology 2006, 6:107-116.
30. Arawaka S, Wada M, Goto S, Karube H, Sakamoto M, Ren CH, Koyama S, Nagasawa $\mathrm{H}$, Kimura $\mathrm{H}$, Kawanami $\mathrm{T}$, et al: The role of G-protein-coupled receptor kinase 5 in pathogenesis of sporadic Parkinson's disease. The Journal of neuroscience: the official journal of the Society for Neuroscience 2006, 26:9227-9238.

31. Nussenweig RS: Human trials of malaria vaccine. Science (New York, NY 1987, 236:763.

32. Murphy K: Janeway's Immunobiology. Book Janeway's Immunobiology. 8 edition. City: Garland Science, Taylor \& Francis Group, LLC; 2012

33. Nemazee D, Buerki K: Clonal deletion of autoreactive B lymphocytes in bone marrow chimeras. Proc Natl Acad Sci USA 1989, 86:8039-8043.

34. Nutt $S L$, Kee BL: The transcriptional regulation of $B$ cell lineage commitment. Immunity 2007, 26:715-725.

35. Hu H, Wang B, Borde M, Nardone J, Maika S, Allred L, Tucker PW, Rao A: Foxp1 is an essential transcriptional regulator of $B$ cell development. Nature immunology 2006, 7:819-826.

36. Kikuchi K, Kondo M: Developmental switch of mouse hematopoietic stem cells from fetal to adult type occurs in bone marrow after birth. Proc Natl Acad Sci USA 2006, 103:17852-17857.

37. Yao Z, Cui Y, Watford WT, Bream JH, Yamaoka K, Hissong BD, Li D, Durum SK, Jiang Q, Bhandoola A, et al: Stat5a/b are essential for normal lymphoid development and differentiation. Proc Natl Acad Sci USA 2006 103:1000-1005.

38. Hoelbl A, Kovacic B, Kerenyi MA, Simma O, Warsch W, Cui Y, Beug H, Hennighausen L, Moriggl R, Sexl V: Clarifying the role of Stat5 in lymphoid development and Abelson-induced transformation. Blood 2006, 107:4898-4906

39. Bain G, Maandag EC, Izon DJ, Amsen D, Kruisbeek AM, Weintraub BC, Krop I, Schlissel MS, Feeney AJ, van Roon M, et al: E2A proteins are required for proper $B$ cell development and initiation of immunoglobulin gene rearrangements. Cell 1994, 79:885-892.

40. Cobaleda C, Schebesta A, Delogu A, Busslinger M: Pax5: the guardian of B cell identity and function. Nature immunology 2007, 8:463-470

41. Lin YC, Jhunjhunwala S, Benner C, Heinz S, Welinder E, Mansson R, Sigvardsson M, Hagman J, Espinoza CA, Dutkowski J, et al: A global network of transcription factors, involving E2A, EBF1 and Foxo1, that orchestrates B cell fate. Nature immunology 2010, 11:635-643.

42. O'Riordan M, Grosschedl R: Coordinate regulation of $B$ cell differentiation by the transcription factors EBF and E2A. Immunity 1999, 11:21-31.

43. Rao DS, O'Connell RM, Chaudhuri AA, Garcia-Flores Y, Geiger TL, Baltimore D: MicroRNA-34a perturbs B lymphocyte development by repressing the forkhead box transcription factor Foxp1. Immunity 2010, 33:48-59.

44. Look AT: Oncogenic transcription factors in the human acute leukemias. Science 1997, 278:1059-1064.

45. Smith $E$, Sigvardsson $M$ : The roles of transcription factors in $B$ lymphocyte commitment, development, and transformation. J Leukoc Biol 2004, 75:973-981.

46. Mullighan CG, Goorha S, Radtke I, Miller CB, Coustan-Smith E, Dalton JD, Girtman K, Mathew S, Ma J, Pounds SB, et al: Genome-wide analysis of genetic alterations in acute lymphoblastic leukaemia. Nature 2007, 446:758-764.

47. Familiades J, Bousquet M, Lafage-Pochitaloff M, Bene MC, Beldjord K, De Vos J, Dastugue N, Coyaud E, Struski S, Quelen C, et al: PAX5 mutations occur frequently in adult B-cell progenitor acute lymphoblastic leukemia and PAX5 haploinsufficiency is associated with BCR-ABL1 and TCF3PBX1 fusion genes: a GRAALL study. Leukemia 2009, 23:1989-1998.

48. Bhojwani D, Howard SC, Pui CH: High-risk childhood acute lymphoblastic leukemia. Clin Lymphoma Myeloma 2009, 9(Suppl 3):S222-230.

49. Mullighan CG, Miller CB, Radtke I, Phillips LA, Dalton J, Ma J, White D, Hughes TP, Le Beau MM, Pui CH, et al: BCR-ABL1 lymphoblastic leukaemia is characterized by the deletion of Ikaros. Nature 2008, 453:110-114.

50. Sun L, Heerema N, Crotty L, Wu X, Navara C, Vassilev A, Sensel M, Reaman GH, Uckun FM: Expression of dominant-negative and mutant isoforms of the antileukemic transcription factor lkaros in infant acute lymphoblastic leukemia. Proc Natl Acad Sci USA 1999, 96:680-685.

51. Nakase K, Ishimaru F, Avitahl N, Dansako H, Matsuo K, Fujii K, Sezaki N, Nakayama $\mathrm{H}$, Yano T, Fukuda S, et al: Dominant negative isoform of the lkaros gene in patients with adult B-cell acute lymphoblastic leukemia. Cancer Res 2000, 60:4062-4065. 
52. Olivero S, Maroc C, Beillard E, Gabert J, Nietfeld W, Chabannon C, Tonnelle C: Detection of different lkaros isoforms in human leukaemias using real-time quantitative polymerase chain reaction. $\mathrm{Br} J$ Haematol 2000, 110:826-830

53. Nishii K, Katayama N, Miwa H, Shikami M, Usui E, Masuya M, Araki H, Lorenzo F, Ogawa T, Kyo T, et al: Non-DNA-binding lkaros isoform gene expressed in adult B-precursor acute lymphoblastic leukemia. Leukemia 2002, 16:1285-1292.

54. Takanashi M, Yagi T, Imamura T, Tabata Y, Morimoto A, Hibi S, Ishii E, Imashuku S: Expression of the Ikaros gene family in childhood acute lymphoblastic leukaemia. Br J Haematol 2002, 117:525-530.

55. Meleshko AN, Movchan LV, Belevtsev MV, Savitskaja TV: Relative expression of different Ikaros isoforms in childhood acute leukemia. Blood Cells Mol Dis 2008, 41:278-283.

56. Mullighan CG, Downing JR: Global genomic characterization of acute lymphoblastic leukemia. Semin Hematol 2009, 46:3-15.

57. Georgopoulos K, Bigby M, Wang JH, Molnar A, Wu P, Winandy S, Sharpe A: The lkaros gene is required for the development of all lymphoid lineages. Cell 1994, 79:143-156.

58. Morgan B, Sun L, Avitahl N, Andrikopoulos K, Ikeda T, Gonzales E, Wu P, Neben S, Georgopoulos K: Aiolos, a lymphoid restricted transcription factor that interacts with Ikaros to regulate lymphocyte differentiation. EMBO J 1997, 16:2004-2013.

59. Streubel B, Vinatzer U, Lamprecht A, Raderer M, Chott A: T(3;14)(p14.1;q32) involving $\mathrm{IGH}$ and FOXP1 is a novel recurrent chromosomal aberration in MALT lymphoma. Leukemia 2005, 19:652-658.

60. Wlodarska I, Veyt E, De Paepe P, Vandenberghe P, Nooijen P, Theate I, Michaux L, Sagaert X, Marynen P, Hagemeijer A, De Wolf-Peeters C: FOXP1, a gene highly expressed in a subset of diffuse large B-cell lymphoma, is recurrently targeted by genomic aberrations. Leukemia 2005, 19:1299-1305.

61. Montecino-Rodriguez E, Dorshkind K: B-1 B cell development in the fetus and adult. Immunity 2012, 36:13-21.

62. Shapiro-Shelef M, Calame K: Regulation of plasma-cell development. Nature reviews Immunology 2005, 5:230-242.

63. Klein U, Tu Y, Stolovitzky GA, Keller JL, Haddad J Jr, Miljkovic V, Cattoretti G, Califano A, Dalla-Favera R: Transcriptional analysis of the B cell germinal center reaction. Proc Natl Acad Sci USA 2003, 100:2639-2644.

64. Odegard VH, Schatz DG: Targeting of somatic hypermutation. Nature reviews Immunology 2006, 6:573-583.

65. McHeyzer-Williams $L$, McHeyzer-Williams MG: Antigen-specific memory B cell development. Annu Rev Immunol 2005, 23:487-513.

66. Klein U, Casola S, Cattoretti G, Shen Q, Lia M, Mo T, Ludwig T, Rajewsky K, Dalla-Favera R: Transcription factor IRF4 controls plasma cell differentiation and class-switch recombination. Nature immunology 2006 7:773-782

67. Cambier JC, Gauld SB, Merrell KT, Vilen BJ: B-cell anergy: from transgenic models to naturally occurring anergic B cells? Nat Rev Immunol 2007, 7:633-643.

68. Bartel DP, Chen CZ: Micromanagers of gene expression: the potentially widespread influence of metazoan microRNAs. Nat Rev Genet 2004, 5:396-400

69. Chen CZ, Li L, Lodish HF, Bartel DP: MicroRNAs modulate hematopoietic lineage differentiation. Science (New York, NY 2004, 303:83-86.

70. Koralov SB, Muljo SA, Galler GR, Krek A, Chakraborty T, Kanellopoulou C, Jensen K, Cobb BS, Merkenschlager M, Rajewsky N, Rajewsky K: Dicer ablation affects antibody diversity and cell survival in the B lymphocyte lineage. Cell 2008, 132:860-874.

71. Xiao C, Srinivasan L, Calado DP, Patterson HC, Zhang B, Wang J, Henderson JM, Kutok JL, Rajewsky K: Lymphoproliferative disease and autoimmunity in mice with increased miR-17-92 expression in lymphocytes. Nature immunology 2008, 9:405-414.

72. Xiao C, Calado DP, Galler G, Thai TH, Patterson HC, Wang J, Rajewsky N, Bender TP, Rajewsky K: MiR-150 controls B cell differentiation by targeting the transcription factor c-Myb. Cell 2007, 131:146-159.

73. Zhou B, Wang S, Mayr C, Bartel DP, Lodish HF: miR-150, a microRNA expressed in mature $B$ and $T$ cells, blocks early $B$ cell development when expressed prematurely. Proc Natl Acad Sci USA 2007, 104:7080-7085.

74. Xiao C, Rajewsky K: MicroRNA control in the immune system: basic principles. Cell 2009, 136:26-36.
75. Meffre E, Casellas R, Nussenzweig MC: Antibody regulation of B cell development. Nature immunology 2000, 1:379-385.

76. He L, He X, Lim LP, de Stanchina E, Xuan Z, Liang Y, Xue W, Zender L, Magnus J, Ridzon $D$, et al: A microRNA component of the p53 tumour suppressor network. Nature 2007, 447:1130-1134.

77. Chang T-C, Wentzel EA, Kent OA, Ramachandran K, Mullendore M, Lee Kwang Â H, Feldmann G, Yamakuchi M, Ferlito M, Lowenstein CJ, et al: Transactivation of miR-34a by p53 Broadly Influences Gene Expression and Promotes Apoptosis. Molecular Cell 2007, 26:745-752.

78. Bommer GT, Gerin I, Feng Y, Kaczorowski AJ, Kuick R, Love RE, Zhai Y, Giordano TJ, Qin ZS, Moore BB, et al: p53-Mediated Activation of miRNA34 Candidate Tumor-Suppressor Genes. Curr Biol 2007, 17:1298-1307.

79. O'Connell RM, Chaudhuri AA, Rao DS, Gibson WS, Balazs AB, Baltimore D: MicroRNAs enriched in hematopoietic stem cells differentially regulate long-term hematopoietic output. Proc Natl Acad Sci USA 2010, 107:14235-14240.

80. Georgantas RW, Hildreth R, Morisot S, Alder J, Liu CG, Heimfeld S, Calin GA, Croce CM, Civin Cl: CD34+ hematopoietic stem-progenitor cell microRNA expression and function: a circuit diagram of differentiation control. Proc Natl Acad Sci USA 2007, 104:2750-2755.

81. Gibcus JH, Tan LP, Harms G, Schakel RN, de Jong D, Blokzijl T, Moller $P$, Poppema S, Kroesen BJ, van den Berg A: Hodgkin lymphoma cell lines are characterized by a specific miRNA expression profile. Neoplasia (New York, NY 2009, 11:167-176.

82. O'Connell RM, Taganov KD, Boldin MP, Cheng G, Baltimore D: MicroRNA155 is induced during the macrophage inflammatory response. Proc Natl Acad Sci USA 2007, 104:1604-1609.

83. Taganov KD, Boldin MP, Chang KJ, Baltimore D: NF-kappaB-dependent induction of microRNA miR-146, an inhibitor targeted to signaling proteins of innate immune responses. Proc Natl Acad Sci USA 2006, 103:12481-12486.

84. Rodriguez A, Vigorito E, Clare S, Warren MV, Couttet P, Soond DR, van Dongen S, Grocock RJ, Das PP, Miska EA, et al: Requirement of bic/ microRNA-155 for normal immune function. Science (New York, NY 2007, 316:608-611.

85. Vigorito E, Perks KL, Abreu-Goodger C, Bunting S, Xiang Z, Kohlhaas S, Das PP, Miska EA, Rodriguez A, Bradley A, et al: microRNA-155 regulates the generation of immunoglobulin class-switched plasma cells. Immunity 2007, 27:847-859.

86. Teng G, Hakimpour P, Landgraf P, Rice A, Tuschl T, Casellas $R$ Papavasiliou FN: MicroRNA-155 is a negative regulator of activationinduced cytidine deaminase. Immunity 2008, 28:621-629.

87. Dorsett Y, McBride KM, Jankovic M, Gazumyan A, Thai TH, Robbiani DF, Di Virgilio M, San-Martin BR, Heidkamp G, Schwickert TA, et al: MicroRNA-155 suppresses activation-induced cytidine deaminase-mediated Myc-Igh translocation. Immunity 2008, 28:630-638.

88. de Yebenes VG, Belver L, Pisano DG, Gonzalez S, Villasante A, Croce C, He L, Ramiro AR: miR-181b negatively regulates activation-induced cytidine deaminase in B cells. The Journal of Experimental Medicine 2008, 205:2199-2206

89. Boldin MP, Taganov KD, Rao DS, Yang L, Zhao JL, Kalwani M, GarciaFlores Y, Luong M, Devrekanli A, Xu J, et al: miR-146a is a significant brake on autoimmunity, myeloproliferation, and cancer in mice. The Journal of Experimental Medicine 2011, 208:1189-1201.

90. Cameron JE, Yin Q, Fewell C, Lacey M, McBride J, Wang X, Lin Z, Schaefer BC, Flemington EK: Epstein-Barr virus latent membrane protein 1 induces cellular MicroRNA miR-146a, a modulator of lymphocyte signaling pathways. J Virol 2008, 82:1946-1958.

91. Kawai T, Akira S: Signaling to NF-kappaB by Toll-like receptors. Trends Mol Med 2007, 13:460-469.

92. Zhao JL, Rao DS, Boldin MP, Taganov KD, O'Connell RM, Baltimore D: NFkappaB dysregulation in microRNA-146a-deficient mice drives the development of myeloid malignancies. Proc Natl Acad Sci USA 2011, 108:9184-9189.

93. Gururajan M, Haga CL, Das S, Leu CM, Hodson D, Josson S, Turner M, Cooper MD: MicroRNA 125b inhibition of B cell differentiation in germinal centers. Int Immunol 2010, 22:583-592.

94. Calin GA, Ferracin M, Cimmino A, Di Leva G, Shimizu M, Wojcik SE, lorio MV, Visone R, Sever NI, Fabbri M, et al: A MicroRNA Signature Associated with 
Prognosis and Progression in Chronic Lymphocytic Leukemia. The New England Journal of Medicine 2005, 353:1793-1801.

95. Calin GA, Dumitru CD, Shimizu M, Bichi R, Zupo S, Noch E, Aldler H, Rattan $\mathrm{S}$, Keating $\mathrm{M}$, Rai $\mathrm{K}$, et al: Frequent deletions and down-regulation of micro- RNA genes miR15 and miR16 at 13q14 in chronic lymphocytic leukemia. Proc Natl Acad Sci USA 2002, 99:15524-15529.

96. Calin GA, Sevignani C, Dumitru CD, Hyslop T, Noch E, Yendamuri S, Shimizu M, Rattan S, Bullrich F, Negrini M, Croce CM: Human microRNA genes are frequently located at fragile sites and genomic regions involved in cancers. Proceedings of the National Academy of Sciences of the United States of America 2004, 101:2999-3004.

97. Mi S, Li Z, Chen P, He C, Cao D, Elkahloun A, Lu J, Pelloso LA, Wunderlich $M$, Huang $H$, et al: Aberrant overexpression and function of the miR-17-92 cluster in MLL-rearranged acute leukemia. Proc Natl Acad Sci USA 2010, 107:3710-3715.

98. Costinean S, Zanesi N, Pekarsky Y, Tili E, Volinia S, Heerema N, Croce CM: Pre-B cell proliferation and lymphoblastic leukemia/high-grade lymphoma in E(mu)-miR155 transgenic mice. Proc Natl Acad Sci USA 2006, 103:7024-7029

99. 99. Costinean S, Sandhu SK, Pedersen IM, Tili E, Trotta R, Perrotti D, Ciarlariello D, Neviani P, Harb J, Kauffman LR, et al: Src homology 2 domain-containing inositol-5-phosphatase and CCAAT enhancer-binding protein beta are targeted by miR-155 in B cells of Emicro-MiR-155 transgenic mice. Blood 2009, 114:1374-1382.

100. Garzon R, Volinia S, Liu CG, Fernandez-Cymering C, Palumbo T, Pichiorri F, Fabbri M, Coombes K, Alder H, Nakamura T, et al: MicroRNA signatures associated with cytogenetics and prognosis in acute myeloid leukemia. Blood 2008, 111:3183-3189.

101. Cimmino A, Calin GA, Fabbri M, lorio MV, Ferracin M, Shimizu M, Wojcik SE, Aqeilan Rl, Zupo S, Dono M, et al: miR-15 and miR-16 induce apoptosis by targeting BCL2. Proc Natl Acad Sci USA 2005, 102:13944-13949.

102. Medina PP, Nolde M, Slack FJ: OncomiR addiction in an in vivo model of microRNA-21-induced pre-B-cell lymphoma. Nature 2010, 467:86-90.

103. Fabbri M, Bottoni A, Shimizu M, Spizzo R, Nicoloso MS, Rossi S, Barbarotto E, Cimmino A, Adair B, Wojcik SE, et al: Association of a microRNA/TP53 feedback circuitry with pathogenesis and outcome of B-cell chronic lymphocytic leukemia. JAMA 2011, 305:59-67.

104. Zenz T, Mohr J, Eldering E, Kater AP, Buhler A, Kienle D, Winkler D, Durig J, van Oers MH, Mertens $D$, et al: miR-34a as part of the resistance network in chronic lymphocytic leukemia. Blood 2009, 113:3801-3808.

105. Chiorazzi N, Rai KR, Ferrarini M: Chronic lymphocytic leukemia. N Engl J Med 2005, 352:804-815

106. Liu Y, Corcoran M, Rasool O, Ivanova G, Ibbotson R, Grander D, lyengar A Baranova A, Kashuba V, Merup M, et al: Cloning of two candidate tumor suppressor genes within a $10 \mathrm{~kb}$ region on chromosome 13q14, frequently deleted in chronic lymphocytic leukemia. Oncogene 1997, 15:2463-2473.

107. 107. Migliazza A, Bosch F, Komatsu H, Cayanis E, Martinotti S, Toniato E, Guccione E, Qu X, Chien M, Murty W, et al: Nucleotide sequence, transcription map, and mutation analysis of the 13q14 chromosomal region deleted in B-cell chronic lymphocytic leukemia. Blood 2001, 97:2098-2104.

108. Klein U, Lia M, Crespo M, Siegel R, Shen Q, Mo T, Ambesi-Impiombato A, Califano A, Migliazza A, Bhagat G, Dalla-Favera R: The DLEU2/miR-15a/16-1 cluster controls $B$ cell proliferation and its deletion leads to chronic lymphocytic leukemia. Cancer Cell 2010, 17:28-40.

109. Lawrie CH, Soneji S, Marafioti T, Cooper CD, Palazzo S, Paterson JC, Cattan H, Enver T, Mager R, Boultwood J, et al: MicroRNA expression distinguishes between germinal center $B$ cell-like and activated $B$ celllike subtypes of diffuse large B cell lymphoma. International Journal of Cancer 2007, 121:1156-1161.

110. Ota A, Tagawa H, Karnan S, Tsuzuki S, Karpas A, Kira S, Yoshida Y, Seto M: Identification and characterization of a novel gene, C13orf25, as a target for 13q31-q32 amplification in malignant lymphoma. Cancer Res 2004 64:3087-3095.

111. 111. Nie K, Gomez M, Landgraf P, Garcia JF, Liu Y, Tan LH, Chadburn A, Tuschl T, Knowles DM, Tam W: MicroRNA-mediated down-regulation of PRDM1/Blimp-1 in Hodgkin/Reed-Sternberg cells: a potential pathogenetic lesion in Hodgkin lymphomas. The American Journal of Pathology 2008, 173:242-252.
112. 112. Pichiorri F, Suh SS, Rocci A, De Luca L, Taccioli C, Santhanam R, Zhou W, Benson DM Jr, Hofmainster C, Alder $\mathrm{H}$, et al: Downregulation of p53-inducible microRNAs 192, 194, and 215 impairs the p53/MDM2 autoregulatory loop in multiple myeloma development. Cancer Cell 2010, 18:367-381.

113. Iborra M, Bernuzzi F, Invernizzi P, Danese S: MicroRNAs in autoimmunity and inflammatory bowel disease: Crucial regulators in immune response. Autoimmunity reviews 2010, 11:305-314.

114. Ronnblom L, Eloranta ML, Alm GV: The type I interferon system in systemic lupus erythematosus. Arthritis and rheumatism 2006, 54:408-420.

115. Pascual V, Farkas L, Banchereau J: Systemic lupus erythematosus: all roads lead to type I interferons. Curr Opin Immunol 2006, 18:676-682.

116. Crow MK: Type I interferon in systemic lupus erythematosus. Current topics in microbiology and immunology 2007, 316:359-386.

117. Tang Y, Luo X, Cui H, Ni X, Yuan M, Guo Y, Huang X, Zhou H, de Vries N, Tak PP, et al: MicroRNA-146A contributes to abnormal activation of the type I interferon pathway in human lupus by targeting the key signaling proteins. Arthritis and rheumatism 2009, 60:1065-1075.

118. Rudensky AY: Regulatory T cells and Foxp3. Immunol Rev 2011, 241:260-268

119. Liston A, Lu LF, O'Carroll D, Tarakhovsky A, Rudensky AY: Dicer-dependent microRNA pathway safeguards regulatory $\mathrm{T}$ cell function. The Journal of experimental medicine 2008, 205:1993-2004.

120. Lu LF, Thai TH, Calado DP, Chaudhry A, Kubo M, Tanaka K, Loeb GB, Lee H, Yoshimura A, Rajewsky K, Rudensky AY: Foxp3-dependent microRNA155 confers competitive fitness to regulatory T cells by targeting SOCS1 protein. Immunity 2009, 30:80-91.

121. Lu LF, Boldin MP, Chaudhry A, Lin LL, Taganov KD, Hanada T, Yoshimura A, Baltimore D, Rudensky AY: Function of miR-146a in controlling Treg cellmediated regulation of Th1 responses. Cell 2010, 142:914-929.

122. Alevizos I, Illei GG: MicroRNAs as biomarkers in rheumatic diseases. Nature reviews Rheumatology 2010, 6:391-398.

123. Krutzfeldt J, Rajewsky N, Braich R, Rajeev KG, Tuschl T, Manoharan M, Stoffel M: Silencing of microRNAs in vivo with 'antagomirs'. Nature 2005, 438:685-689

doi:10.1186/1756-8722-5-7

Cite this article as: Fernando et al: MicroRNAs in B cell development and malignancy. Journal of Hematology \& Oncology 2012 5:7.

\section{Submit your next manuscript to BioMed Central and take full advantage of:}

- Convenient online submission

- Thorough peer review

- No space constraints or color figure charges

- Immediate publication on acceptance

- Inclusion in PubMed, CAS, Scopus and Google Scholar

- Research which is freely available for redistribution

Submit your manuscript at www.biomedcentral.com/submit
C Biomed Central 